\title{
ВІЙСЬКОВА СПРАВА НА ГАЛИЦЬКО-ВОЛИНСЬКИХ ЗЕМЛЯХ У V-IX ст. (ЗА АРХЕОЛОГІЧНИМИ ДЖЕРЕЛАМИ)
}

Стаття присвячена аналізу витоків військової справи на процесу формування спільнот місцевих дружинників на землях Східного Прикарпаття та Волині у V-IX ст. За археологічними знахідками із галицько-волинських земель проаналізовано військове спорядження періоду раннього середньовіччя. 3'ясовано походження елементів захисного та наступального озброєння, спорядження вершника і коня. Неодноразове виявлення у Західному Побужжі археологічних знахідок такого наступального озброєння, як меч, є показником початків становлення професійної дружини ще на початку раннього середньовіччя.

Ключові слова: раннє середньовіччя, археологічні знахідки, спис, меч, галицько-волинські землі.

Актуальність теми визначається тим, що дослідження процесу виділення професійного військового стану у східних слов'ян $є$ важливим аспектом становлення державності на племінному етапі. За останні десятиліття з'явився значний археологічний матеріал для характеристики матеріальної бази ранньосередньовічної військової справи. Ці знахідки дають змогу поставити питання про ранні етапи слов'янської державності, різнобічно характеризувати іiі розвиток та творення військової культури на західних землях України.

Важливим фактором процесу творення військового стану у слов'ян за доби великого переселення народів була тісна взаємодія з сусідніми етносами: давніми германцями, римлянами, гунами, аварами, яка супроводжувалась запозиченням ефективних зразків озброєння та способів бою [19]. Ці запозичення на початкових етапах становлення військової справи у давніх українців часто відбувалися за умови участі в складі поліетнічних дружин. Поліетнічність дружин за доби великого переселення народів добре помітна при аналізі саме військового інвентарю.

Терський Святослав Володимирович, доктор історичних наук, професор кафедри історії, музеєзнавства i культурної спадщини Національного університету «Львівська політехніка».

(C) Терський С.В., 2018 
Стан дослідження проблеми. Становлення кінноти у східних слов'ян в контексті формування спорядження вершника вже розглядався автором за археологічними знахідками з галицьковолинських земель. Натомість з'явилася низка досліджень 3 окремих аспектів військової справи у східних слов'ян у V-IX ст. Також досліджувалась роль різноманітних військових традицій у формуванні давньоукраїнського війська, як-то степової чи германської. Окрім українських істориків (М. С. Грушевський, I. П. Крип'якевич, Л. В. Войтович, В.І.Кійко) велику увагу археологічним аспектам прояву цих впливів на військову справу приділяли А. М. Кірпічніков, А. Ф. Медведєв, В. М. Петегирич, С. В. Пивоваров, І. П. Возний, П. М. Котович та автор даної публікації.

Новизна дослідження. За останні десятиліття значно зросла джерельна база стосовно різних сторін давньої історії українського війська, дослідниками зібрано ряд фактів, які дозволяють детальніше з'ясувати обставини формування перших військових спільнот у східних слов'ян. Проте поява ряду окремих досліджень не призвела до створення загальної картини початків формування професійного війська на галицько-волинських землях у V-IX ст. $[8 ; 9 ; 10 ; 11]$, ще потребує ретельнішої деталізації.

Метою статті є аналіз сучасних історичних досліджень проблеми, а також особливостей джерельної бази, що стосується початкових етапів формування давньоукраїнського війська.

Виклад основного матеріалу й обтрунтування отриманих результатів дослідження. Мешканці галицько-волинських земель 3 давніх часів контактували то 3 войовничими племенами Східної Прибалтики, то з вічно мандруючими степовиками.

Доба великого переселення народів - важливий, проте малодосліджений історичний період в історії західноукраїнських земель. Досі археологам масштабно не вдається виділити пам'ятки цього часу на галицько-волинських землях.

Проте з року в рік зростає кількість знахідок, які репрезентують цей період. Вони демонструють присутність на галицько-волинських землях на сьогодні погано вловимої військової і державної еліти.

Визначальним є відоме Зимнівське городище у Західному Побужжі, під час досліджень якого встановлено концентрацію 
знахідок озброєння VI-VII ст. Таку концентрацію озброєння пояснюють тим, що на городищі існував своєрідний «дружинний арсенал», де зброя не лише зберігалася, але й вироблялася та ремонтувалася [11, с. 116]. За іншою версією тут було традиційне для степовиків жертовне місце.

Присутність значної кількості озброєння та предметів елітарного вжитку (предмети ювелірного ремесла) дозволили пов'язати Зимнівське городище в околицях княжого Володимира найдавніший укріплений центр слов'янської Волині, 3 державотворчим ядром племінного об'єднання дулібів у Побужжі. Тут знайдено 18 цілих та фрагментованих списів i дротиків, один 3 яких аварського типу, а також декілька аварських трилопатевих стріл [3, с. 49]. Ще одне аварське вістря списа (дротика?), орнаментоване при переході від пера до втулки ланцюжковим орнаментом із ромбів VII ст., знайдено неподалік Зимного, в околицях городища Городок-над-Бугом. На думку дослідників, цей укріплений центр загинув наприкінці VII ст. внаслідок ворожого нападу.

Про присутність кочової еліти свідчить також значна кількість інших знахідок пам'яток аварської доби у Західному Побужжі (Зимно, Городок-над-Бугом, Стефановичі, Ріпнів) [2; 10, с. 111].

Як відомо, найтиповішою зброєю в руках слов'янського воїна, починаючи з VI ст., як свідчать джерела, був опис. Але спочатку списи служили лише подібно до римських дротиків для кидання, i тільки в IX-X ст. наступає новий період у розвитку і використанні списа. Літописи часто згадують про "взятие города копьем" [9].

Тому не випадковою видається знахідка в цьому ж регіоні Західного Побужжя двох порівняно рідкісних мечів ранньоісторичного періоду. Один із них довжиною з черешком 93 см був знайдений на початку 1930-х років неподалік від Володимира, на березі р. Буг біля с. Вигаданка (тепер с. Амбуків) навпроти городища у Городку-над-Бугом разом із шоломом і черепом, який селяни відразу кинули назад у річку [13, рис. на с. 31]. Він зберігався спершу у музеї НТШ у Львові (№ 23530), а потім - у Львівському історичному музеї [ЛІМ-135, ЛІМ-3-1213, див. 12, с. 219]. Інший, довжиною 92 см, влітку 2012 р. знайшли на дні р. Західний Буг на північній околиці м. Червонограда Львівської обл. [13, с. 7]. 
Обидва мечі відносяться до однієї 3 форм т.зв. «Спати» раннього середньовіччя, яка в свою чергу була, певною мірою, подальшим розвитком довгих двосічних мечів попередньої епохи. Згідно із спостереженнями цього автора, даний тип веде своє походження від довгих мечів алано-сарматського населення Північного Причорномор'я, а пізніше в дещо видозміненій формі його переймає та частина германських племен (в основному готи), які переселилися сюди в кінці III - на початку IV ст. [13, c. 9-10]. У сучасній історіографії зазначений тип меча отримав назву «азіатського». Судячи із знайденого матеріалу, він набуває поширення в тих регіонах, де найбільш тісно відбувався контакт між лісовими і степовими племенами «епохи переселення народів», тобто у південній частині Східної та Центральної Свропи [13, с. 10].

Ці мечі мають декілька аналогій, дві 3 яких походять 3 Північного Причорномор'я - із с. Дмитрівка, Запорізька обл. та із Тамані Краснодарського краю в Росії, а дві - 3 кладовищ Північно-Західного Кавказу: Мокра Балка та Лермонтівська Скала. У всіх цих мечів є одна відмінна ознака - на хвостовику змонтована коротка і широка хрестовина, оздоблена в техніці перегородчастої інкрустації, де в пластинку 3 невеликими комірками, зроблену, як правило, 3 дорогоцінних металів, вставлялися в певному порядку шматочки гранату, сердоліку або скла, таким чином, утворюючи ошатний орнамент. Встановлено, що подібна зброя належала до категорії статусної. Тому цей тип зброї часто знаходять разом 3 іншим багато декорованим інвентарем, зокрема з деталями поясної гарнітури, яка зроблена в подібній техніці, золотими фібулами та іншими предметами, що вказують на високе соціальне становище похованого. На думку археолога М. М. Казанського, який досліджує особливості матеріальної культури епохи Великого переселення народів, знайдені мечі могли належати або вождям племен, які кочували у 2 пол. V - поч. VI ст. в степах Північного Причорномор'я і Північно-Західного Кавказу, або їх найближчому оточенню, оскільки саме у вказаному регіоні $є$ найбільша концентрація знахідок [6, с. 240-241]. Також дослідник припускає, що зброя цього типу була візантійським імпортом, піднесеним в якості дарунків кочовим «федератам» Візантії [6, с. 241]. 
Окрім зазначених вище знахідок схожі клинки відомі у Центральній Європі і походять 3 двох багатих поховань «гунського» часу (кін. IV-1 пол. V ст.), розкопаних в Угорщині, а також двох мечів із поховань періоду гунського панування в Центральній Європі, досліджених на території Польщі [13, с. 10-11].

Розглянуті аналогії до двох клинків із Західного Побужжя дозволили продатувати цю зброю широким хронологічним відтинком - кінцем IV - початком VI ст. Однак присутність бронзової чи латунної хрестовини на одному з мечів дозволила перенести датування клинка на VI-VII ст. [13, с. 11].

Про тривкі традиції військової культури у Західному Побужжі свідчать не лише знахідки пам'яток гунської та аварської доби. Зокрема, саме на цій території зафіксовано концентрацію знахідок характерної для війська Великої Моравії зброї VIII-IX ст.чеканів типу «брадатіца» [20, с. 24].

Кому ж могли належати ці пам'ятки дружинного середовища? Чи потрапили вони в землю вони як свідчення випадкових переходів іноземних дружин, чи належали місцевим воїнам?

3'ясувати це питання можуть пошуки тогочасної військової еліти. Для V ст. такою елітою у Центрально-Східній Свропі були, поза всяким сумнівом, гуни та їх союзники. Як відомо, ставка попередників Аттіли (до часу ii перенесення в Паннонію) могла знаходитися десь в Північно-Західному Причорномор’ї [4, с. 13]. Загалом про гунів у Центрально-Східній Європі відомо в основному після перенесення їх ставки близько 420 р. в Паннонію.

Як відомо, саме степові племена були генераторами багатьох нововведень у військовій сфері. Степові запозичення загалом були особливістю дружинного спорядження на Сході Свропи. Про ці запозичення свідчать характерні знахідки предметів спорядження верхового коня (вудила, стремена, деталі сідла, оздоби збруї, підпружні пряжки, застібки від пут і недоуздка) та засоби керування (навершя руків'я батогів) [15]. 3 гунами слід пов'язувати поширення в Європі, починаючи 3 V-VI ст., характерних тридільних кілець-розподільників. Їх знайдено в комплексах VI-VII ст. в Рашкові та Зимному [14].

Як відомо, перші стремена, які з'явились на Далекому Сході в IV-V ст. н.е., а згодом потрапили до аварів, які в цей час рухалися на захід, за їх посередництвом наприкінці VI ст. були занесені в Європу [17]. 
Пошукам військової еліти V-VI ст. на західноукраїнських землях може допомогти низка давно відомих археологічних пам'яток, якщо встановити між ними причинно-наслідковий зв'язок.

Так, однією з широковідомих елітарних пам'яток Подністров'я гунської доби є залишки скловиробничої майстерні в Комарові Кельменецького р-ну Чернівецької обл. На сьогодні вона досі залишається єдиною 3 відомих на сьогодні скловиробничих центрів за межами Імперії, що існував, як припускають, не раніше другої половини IV ст. і може належати періоду, коли класичні черняхівські комплекси вже не існували [4].

Про перебування певний час на цій території гунської або аланської вершницької аристократії після 70-х років IV ст. може свідчити також високого рівня золотарська майстерня, досліджена на поселенні Бернашівка на середньому Дністрі, яка виготовляла оздоби у візантійському стилі на початку VI ст. В ній зібрано 64 ливарних форми 3 місцевого дністрянського вапняку i мергелю, призначені для виготовлення оздоб, передовсім, дружинного спорядження [5].

Кочівницькій аристократії, насамперед сармато-аланської, належали також характерні еліпсоїдні масивні намистини 3 халцедону, знайдені у Східному Прикарпатті [1]. Намистини, що виконували функцію підвіски до плечей, поширилися на широкій території від Кавказу до Рейну під впливом престижної середземноморсько-візантійської моди [7].

Лише потужна державна верхівка могла замовити для своїх потреб вишукані оздоби військового спорядження та відтворити одну 3 найпрезентативніших ознак провінційно-римського життя тонкостінний скляний, в т.ч. різнокольоровий і нерідко пишно декорований посуд, сама форма якого свідчила про вишуканий смак, високі естетичні вподобання і фінансову спроможність господаря.

Чи не гунська або гуно-аланської верхівка була спроможна запросити для задоволення своїх вибагливих матеріальних потреб будівничих і ремісників 3 дунайсько-чорноморських провінцій?

3 переміщенням степовиків на терени Українського лісостепу (Поділля, Волинська височина) прийнято пов'язувати появу коштовних скарбів кінця IV - початку V ст.: Борочицького, 
Бранівського, Качинського та ін. сконцентрованих в незначному регіоні на та поруч Волинської височини. Припускають, що в таких важливих транскомунікаційних районах як Середнє Подністров'я чи Західне Побужжя, могли знаходитися адміністративно-політичні центри тогочасної гунської держави [4, с. 12]. Перелічені волинські скарби не могли бути приналежними до панівної кінця IV ст. на Волині Вельбарської культури, оскільки для неї вони не притаманні. Належність волинських скарбів гунам, які у середині 420-х років переходили на Середній Дунай припускав також відомий знавець археології доби великого переселення народів Я. Тейрал.

Однак із відомим за писемними джерелами відходом гунів 3 Свропи породжена ним дружинна активність на Волині не зникає, свідченням чого $\epsilon$ функціонування Зимнівського городища у VI-VII ст., а також синхронний йому скарб сасанідського срібла, знайдений у 1823 р. поблизу с. Хоняків Острозького повіту. Цей скарб, що включав у свій склад срібне начиння іранської роботи VII ст. та золоті монети, було приписано легендою польському королю Станіславу Лещинському. Однак через майже сто років окремі предмети з цього скарбу, що розійшлись серед колекціонерів, потрапили в поле зору науковців [19] та були опубліковані.

Знайдений поблизу відомого степового коридору на півночі сучасної Хмельниччини скарб міг також належати пов'язаній своїм походженням зі степом дружинній еліті. Свідченням цього $\epsilon$ виявлення на початку XX ст. в околицях Шепетівки в одному 3 підкурганних поховань VIII ст. у с. Клементовичах [21] елементів, притаманних похованням степовиків: кісток коня та характерної для них кістяної підпружної пряжки.

Як відомо, анклави степу, що мали поширення у верхів'ях р. Горинь та Случ, а також на території східніше Дністра (частина Волині північніше верхів'їв Південного Бугу та район степу Панталиха на Правобережжі Збруча в давнину не пустували [16]).

Таким чином, є достатньо доказів того, що на західноукраїнських землях за доби Великого переселення народів відбувалася передача військових знань і традицій від кочової військової аристократії до місцевого слов'янського населення. Ключовими місцями цього співробітництва, за наявними даними 
були транзитні регіони в Західному Побужжі та Середньому Подністров ї. Саме тут у наступний період - IX-X ст. формуються племінні «князівства» волинян та східних карпатських хорватів.

1. Фонди Львівського історичного музею. Група «Київська Русь».

2. Ауліх В. В. Металеві пряжки і прикраси з верхнього горизонту городища в с. Зимне, Волинської області / B. В. Ауліх // Матеріали і дослідження 3 археології Прикарпаття та Волині (далі - МДАПВ).- Вип. 4.- К.: Вид-во АН УРСР, 1962.- С. 92-105.

3. Ауліх В. В. Зимнівське городище - слов'янська пам'ятка VI-VII ст. у Західній Волині / В. В. Ауліх.- К.: Наук. думка, 1972.- 123 с.

4. Бандрівський Микола. Про ймовірний вплив гунської навали на появу скловиробничої майстерні в Комарові на північній Буковині / М. Бандрівський // Археологія Буковини: здобутки та перспективи: тези доповідей наукового семінару (м. Чернівці, 15 грудня 2017 р.). - Чернівці: Технодрук, 2017. - С. 9-13.

5. Винокур I. С. Слов'янські ювеліри Подністров'я / I. С. Винокур. - Кам'янець-Подільський, 1997.

6. Казанский М.М. Ранневизантийские мечи с инкрустированной гардой / М.М. Казанский // Засецкая И.П., Казанский М.М., Ахмедов И.Р., Минасян Р.С. Морской Чулек. Погребения знати из Приазовья и их место в истории племён Северного Причерноморья в постгуннскую эпоху. - СПб.: Изд-во Гос. Эрмитажа, 2007. - С. 122-141.

7. Мастыкова А. В. Халцедоновые бусы элипсоидной формы эпохи раннего средневековья: распространение, датировка, социальная атрибуция / A. В. Мастыкова // Российская археология.- 2001.- № 2.- С. 23-37.

8. Панікарський A. Двокрилі вістря стріл зі слов'янських ранньосередньовічних пам'яток півдня східної Європи / A. Панікарський // Археологічні дослідження Львівського університету.- Львів, 2014.Випуск 18.- С. 111-127.

9. Панікарський А. Списи та дротики ранніх слов'ян: функціональна класифікація / A. Панікарський // Археологія. - 2015. - № 1. - С. 39-50.

10. Петегирич В.M. Поселенські структури V/VI-X Верхньої Надбужанщини як підоснова формування Белзької та Червенської земель / В.М. Петегирич // МДАПВ.- Вип. 11.- Львів: Ін-тут українознавства НАНУ, 2007.- С. 101-120.

11. Синиия $€$. Перунові діти. Військова справа слов'ян на початку середньовіччя / Є. Синиия.- К., 2012.- 276 с. 
12. Терський C. В. Княже місто Володимир.- Львів: Вид-во Національного університету “Львівська політехніка", 2010.- 320 с., іл.

13. Терський C.B. Нові знахідки ранньосередньовічної зброї у р. Західний Буг / С.В. Терський, О.В. Стрельченко, В.М. Войнаровський // Вісник Національного університету “Львівська політехніка".- № 809: Держава та армія.2014.- C. 7-12.

14. Терський С. В. Ремінні трійники-розподільники VI-XIII ст. на Правобережжі України / C.В. Терський // Наукові записки (Рівненський краєзнавчий музей).- Вип. 13.- Ч. 1.- Рівне, 2015.- С. 176-179.

15. Терський С. В. Формування кінноти у слов'ян VI-XI ст. на Правобережжі України / С.В. Терський // Військовонауковий вісник.- Вип. 24.- Львів: АСВ, 2015.- С. 29-39.

16. Терський C.B. Утвердження Київської держави у Східному Прикарпатті та Волині: стан джерел та наукові версії / С.В. Терський, Б.А. Омельчук // Historical and cultural studies.- № 4.- 2017.- C. 81-86.

17. Худяков Ю. С. «Свистящие стрелы» Маодуня и «Марсов меч» Аттилы: Военное дело азиатских хунну и европейских гуннов / Ю. С. Худяков, В. П. Никоноров. СПб, 2004. - 320 с.

18. Цинкаловський О. Княжий город Володимир / О.Цинкаловський.- Луцьк: Надстир'я, 2003 (Львів: Просвіта, 1935).- 124 с.

19. Beńkowski P. O skarbie srebrnym z Choniakowa na Wołyńiu / P. Beńkowski // Światowit.- 13.- 1929.- 37 s.

20. Kotowicz $P$. Przemiany w uzbrojeniu plemiennym i wczesnopaństwowym (VI - poł. XIII w.) w polskiej części dawnych księstw ruskich - wybrane przykłady / P. Kotowicz // ВНУ “ЛП”.- № 571: Держава та армія.- 2006. - С. 18-47.

21. Musianowicz, K. Cmentarzysko kurhanowe z VI-VIII w. w Klementowiczach kolo Szepetówki (USSR) / K. Musianowicz // Wiadomości archeologiczne.- T. 39.-1975.-Z. 3.-S. 100-104.

Надійшла до редколегії 10.09.2018 р.

\section{Tersky S.}

WARFARE IN THE GALICIAN-VOLYN LANDS IN THE V-IX CENTURIES (BY ARCHAEOLOGICAL SOURCES)

The article is devoted to the analysis of the origins of military affairs on the process of forming communities of local militants on the lands of the Eastern Carpathians and Volhynia in the V-IX centuries. According to archaeological finds from the Galician-Volyn lands, military equipment of the early Middle Ages was analyzed. The origin of elements of protective and offensive weapons, equipment of a rider and a horse is revealed. Repeated discovery in the basin of Western Bug of archaeological finds of such offensive weapons as a sword is an indicator of the beginning of the formation of a professional military squad at the beginning of the early Middle Ages.

Keywords: early Middle Ages, archaeological finds, spear, sword, Galician-Volyn lands. 